University for Business and Technology in Kosovo

UBT Knowledge Center

Oct 28th, 9:00 AM - Oct 30th, 5:00 PM

\title{
Application of DCF method in the assessment of company's capital - with a study case
}

\author{
Bukurie Imeri Jusufi \\ University for Business and Technology, bukurie.jusufi@ubt-uni.net \\ Sema Kazazi \\ University for Business and Technology, sema.kazazi@ubt-uni.net
}

Follow this and additional works at: https://knowledgecenter.ubt-uni.net/conference

Part of the Business Commons

\begin{abstract}
Recommended Citation
Jusufi, Bukurie Imeri and Kazazi, Sema, "Application of DCF method in the assessment of company's capital - with a study case" (2016). UBT International Conference. 27. https://knowledgecenter.ubt-uni.net/conference/2016/all-events/27
\end{abstract}

This Event is brought to you for free and open access by the Publication and Journals at UBT Knowledge Center. It has been accepted for inclusion in UBT International Conference by an authorized administrator of UBT Knowledge Center. For more information, please contact knowledge.center@ubt-uni.net. 
APPLICATION OF DIJKSTRA ALEGORITHM TO DEFINE THE LOWER PRICE IN THE DISTRIBUTION NETWORK OF SUPPLING

\title{
Application of DCF method in the assessment of company's capital - with a study case
}

\author{
Bukurie Imeri Jusufi ${ }^{1}$, Sema Kazazi ${ }^{2}$ \\ ${ }^{1,2}$ UBT - Higher Education Institution, Lagjja Kalabria, 10000 p.n., \\ Prishtine, Kosovo \\ \{bukurie.jusufi ${ }^{1}$, sema.kazazi $\left.{ }^{2}\right\} @$ ubt-uni.net
}

\begin{abstract}
The models based on assets, dividents, cash flow and returns are identical, however, in the real world, a perfect environment does not exist, thus the results of the models applied throughout the assessment of the companies are different. Therefore, in such an environment, the data used during the capital assessment represent the assessment of the future values and their measurement is important during the predictions.

The aim of the study is to explain the concept of 'market real value' of the companies and the methodological instrumentarium for their assessment, with a special focus on the factors that influence the company's capital value.

Within the scope of the methodological instrumentarium for the assessment of the companies based on the dynamic assessment methods it will be discussed how the financial and contable risks are incorporated in the company's capital value. The methods applied in the study case will be the method of the discount cash flow (DCF), which will be further materialized in three scenarios: basic, optimistic and pesimistic.

For each sceanrio, the relevant factors that determine the elements of cash flow are researched. Each scenario predicts a complete analysis of the company's economy, of its demand and performance. It is formed by the 'basket" of all hypothesis put together and it represents a new hypothetical situation in which the company finds itself.
\end{abstract}

Keywords: capital, market real value, assets, dividend, risk.

\section{Introduction}

A company's real value is a condition for a precise presentation of the company's state, in front of investors and creditors. The power to meet the needs, the nature, growth and development of the companies is also conditioned by this, as well as the contribution of the companies to the development of the national economy, by applying models for estimating the value of their capital.

The subject of discussion in this paper is the hypothesis of a "fair market price" of companies and the methodological instrumentarium for their valuation, that is, the real valuation by the market, or analysis of the companies that are listed on the stock market with a methodological valuation and what are the factors that have an impact, because of which we have a deviation of the market and the book value, i.e the real versus the market stock price. 
A special overview has been made to the factors that condition the value of a company's capital. In that context, business risk analysis and their quantification and incorporation in the capital's value, has a crucial meaning.

This paper contains detailed explanations of the ways to predict risks, risk assessment, to which degree can the same risk assessment models be implemented in both developed and developing economies, including our country and the problems that occur, all of which is in order to estimate the price of the capital, the risk exposure and risk management in the business environment.

Within the methodological instrumentarium for company assessment, according to the dynamic assessment methods, it is shown how risks are incorporated into the capital's value in the companies.

\section{Overview of the valuation models}

In the economic literature there are a few methods to valuate companies, which are used by analysts and investors. In a perfect world, models based on means, dividends, cash flows and earnings are identical, but in reality this highly stylized surrounding doesn't exist and the results from the models can differ. The data used in the valuation models represent an estimate of the expected future values and their measurement is as important as their ability for prediction.

One group of methods are based on accounting principles, knowing that "accounting contains the elements of a complete information system, that synchronizes the basic elements that compose this information system, establishes their organization, creates the methodology, determines the means and chooses and uses needed data and information". The second group is based on the theory of investments. The first group of methods relies on the valuation models based on means (net assets) by accounting principles, whereas the second one is made of methods which are based on establishing the current value of the expected future proceeds. Alongside these methods, there are plenty of other combined methods that have been developed. The following are some of the more famous company valuation methods:

-market way: valuation by market stock value

-method of discounted cash flow

-company valuation method by the value of the net-substance calculated from its current value of expected gains

-method of capitalization of normalized gain

-method of corrected accounting value of the capital

-method of establishing discounted value of expected gross-earnings

-method of establishing liquidation value of the company

-combined methods for establishing the value of a company, by which the value is achieved as an average value of the net-substance value and the discounted value of the expected netearnings

-method of extra-profit

-combined method for valuation of the companies, achieved as a sum of the net-substance value and the goodwill value.

-method of valuation based on comparing indicators with similar companies - method of comparing companies and other methods.

Below, we will research a third category, that has the characteristics of the first two, abnormal earnings or the Edwards-Bell-Ohlson (EBO) model. 


\section{APPLICATION OF DIJKSTRA ALEGORITHM TO DEFINE THE LOWER PRICE IN THE DISTRIBUTION NETWORK OF SUPPLING}

The valuation models based on means, give value to the company, based on the current market value of each individual rate of the means. The obligations are deducted in order to get to the value of the owner's equity (capital), "equity" of the company.

Value $=$ means - obligations

In DCF models, the time value " $t$ " is determined like a current value of future cash flows:

$$
\text { Value }_{\mathrm{t}}=\sum_{i} \frac{C F_{t+1}}{(1+r)^{i}}
$$

Where $C F_{t+i}$ represents expected cash flows ,i” in a period of time ,t” and ,r" is the discount factor (demanded rate of company's yield). DCF models can vary depending on the appropriate measurement of the cash flow $\mathrm{CF}$, defined differently as a flow of future dividends, earnings or free cash flows.

The uncertainties in these models include: -difficulties in valuation of the final horizon

-the nature of the cash flows and earnings and difficulty in evaluation, whether the published amounts are permanent (will persist in the future) or transitory (will not repeat).

-valuation of the means, earnings and cash flows, which could be influenced by the choice of accounting policies or discretionary policies of management.

\section{Valuation modes of discounted cash flows}

Parameters that made up the DCF model:

$$
\text { value }=\sum \frac{C F_{t+1}}{(1+r)^{i}}
$$

They are connected to the risk (demanded income rate) and the income itself (CF-cash flow). These models originated in the finance litterature that use three alternative CF measurements: dividends, accounting gains and free cash flows. As the DCF models of valuation based on means are equivalent, under the assumption that perfect markets exist, the dividents, earnings and measurments of free cahs flows have to show that they carry equivalent results. Their implementation is not that simple.

There is a difficulty in defining cahs flows that are used in these models. They are defined differently, depending if the valuation goal is the company's capital (shown as R) or the value of the debt of the company plus the capital (V).

The models need future cahs flows as imput. How are the cahs flows determened with using current data, are the current and past dividends, earnings or cash flows the best indicators of that flow?

\section{Valuation of the company by using the DCF method}

The valuation method of the company, according to the amount od the discounted cahs flow, i.e DCF method is the most typicaly used investment method. Unlike the concept of gain, the cash flow includes the cash net-inflows that are made in the company and are left on disposal to the investor. 


\section{Book of Proceedings}

International Conference on Management, Business and Economics

The same as in the case of the method of valuation of the company according to gains, in this approach, the goal is to determine the value of the company's own capital. But, the difference is in the determination effect - which is the cash flow instead of gain.

In the approach in the evaluation of the company's own capital, its value will be achieved if from the current value of the cash flow we deduct the long-term company debt. The cash flow, like a base for valuation of the joint venture (company), is made of the following elements:

-Net-gain before tax and tax payment (EBIT)

1.depreciation

2.growth of net-turnover capital (investments in turnover means)

3.investments in fixed means.

In the projections, we use the scenario analysis. Three scenarios are prepared - optimistic, pessimistic and most probable (base).

In order to perform a scenario-analysis, one needs to study the relevant factors that determine the elements of the cash flow of inflows and outflows.

Each scenario assumes a complete analysis of the company's environment, the demand and its performances in different assumed working conditions, the sensitivity in certain changes in the key variables. Each scenario is formed from "a basket" of assumptions taken together at the same time. Each scenario represents a new hypothetical situation in which the company might find itself. The assumed situations derive from an analysis of different situations in which the company can find itself in the future according to its available potential, the competition, the financial power of the company etc. In that way we conduct different scenarios. As a result of each scenario, we project the balance of success and condition, as well as an overview of the cash flow and then, we form an overview of the discounted cash flow.

From each scenario, derives an estimated value of the company. We can chose a value according to one of the scenarios, but it can also form a value according to a pondering, arithmetic average of all three scenarios, wherein ponders would be the coefficients of probability which we could determine as our own view. This view derives from the analysis of the strong and weak points in each scenario.

In fact, through separate scenarios we determine the limits of the company's value - the highest and the lowest. In the end, we examine the sensitivity of the acquired values, as well as the influence of the change of the key variables - the length of the projection period, the discount rate, changes in the prices of the expenses etc. With their examination we can clear up the concept of company value.

The estimate of the company's value becomes a valuable information for the management, shareholders and all other interested parties - present and potential. In case of a sale of the company, the estimate of the buyer and seller gives solid arguments and information to negotiate and came to a "fair price" that could be acceptable for transaction by both parties.

In this part, we evaluate the shareholders' capital of five companies that are ranked on the Macedonian stock market, by the method of discounted cash flows. The companies in question are: Alkaloid AD, Replek AD, Komercijalna Banka AD, Granit AD and ZK Pelagonija.

In Attachment 1, we have stated the models for determining the capital value of Alkaloid AD, Replek $\mathrm{AD}$, Komercijalna Banka AD, Granit AD and ZK Pelagonija. Each scenario is formed from a "basket" of assumptions taken at the same time and together, and it represents a new hypothetical situations in which the company can find itself. The assumed situations derive from analysis of different situations in which the company can find itself in the future, according to its available potential, the competition, the financial power of the company etc. Since all companies function under the same surroundings and 


\section{APPLICATION OF DIJKSTRA ALEGORITHM TO DEFINE THE LOWER PRICE IN THE DISTRIBUTION NETWORK OF SUPPLING}

in the same time frame, the assumptions are the same in all three scenarios. It should be taken in consideration that all companies are not from the same field or size.

The assumptions in the base scenario are as follows: a $2 \%$ increase in income, consequently $-1.5 \%$ increase in expenses. The discount rate in the specific case will be $9 \%$, since we don't have the $\beta$ coeficient as a factor for determining the WACC, we got the discount factor as interest rate of longterm loans (credits) which is $7 \%$ and on that rate, a $2 \%$ activity risk has been added (attachment 1).

Based on the abovementioned assumptions of the base scenario, the capital value of Alkaloid AD, Replek AD, Komercijanlna Banka AD, Granit AD and ZK Pelagonija, stated in euros by the average exchange rate of the euro, $1 €=61.3$ den, is given in chart 1 .

In the optimistic scenario, the assumptions are as follows: $5 \%$ increase in the sale's income and 2\% increase of the expenses, the other indicators remain the same as in the base scenario, with the capital value of the companies given in chart 3.23.

In the pessimistic scenario, we have based the assumtions on less than favorable conditions, meaning: $1 \%$ increase in income, $1.5 \%$ increase in expenses. With assumptions like these the capital value decreases, in this specific case, it is shown in chart 1.

\begin{tabular}{lllll}
\multicolumn{4}{c}{ Chart 1. Capital value of the companies calculated with DCF method } \\
\hline Companies & $\begin{array}{l}\text { Capital Value } \\
\text { Base scenario }\end{array}$ & $\begin{array}{l}\text { Capital } \\
\text { Optimistic } \\
\text { scenario }\end{array}$ & $\begin{array}{l}\text { Value } \\
\text { Capital } \\
\text { Pessimistic } \\
\text { scenario }\end{array}$ & Value \\
\hline $\begin{array}{l}\text { Komercijalna } \\
\text { AD }\end{array}$ & 135.914 .651 & 155.461 .445 & 114.889 .062 \\
GD Granit & 172.209 .791 & 175.332 .381 & \\
Replek AD & 43.044 .816 & 46.220 .522 & 34.577 .175 \\
ZK Pelagonija & 38.945 .429 & 59.625 .517 & 28.116 .651 \\
Alkaloid AD & 33.711 .701 & 54.030 .046 & 32.781 .036 \\
\hline
\end{tabular}

Source: Personal calculations by given assumptions

Based on this valuation model, the capital of Komercijalna Banka AD in chart 3.23 is valued higher then the construction company Granit AD, followed by Replek AD etc.

\section{Conclusion}

The actuality of this problem derives from the connection between the risk, income and the influence of the business and the general surroundings on the companies, and consequently on their market value. The discussion about the models of valuation based on means includes reexamining of the influence of the dividend policy, owner's transactions, procurements, changes in currency and the accounting methods of the net-means. These reviews reinforce the view that the economic and accounting factors should be taken in consideration when using financial data. Establishing market value on long-term means like: building facilities, machines and equipment, is a difficulty when using valuation based on means for more companies, where the ratio between (corrected) accounting value and market price is under the influence of this mistake during measurement. 
Book of Proceedings

International Conference on Management, Business and Economics

\section{References:}

1. Gerald I. W., Ashwinpaul C. S. and Dov F "The analysis and use of Financial Statement" 1998 by John Wiley\& Sons. Inc.

2. Saunders A, Coornett M. M. "Financial institutions management, a risk management approach", sixth edition, Mc graw-Hill Irwin, 2008 year

3. http://www.mse.com.mk

4. Financial Statement of the company 